\title{
Why should an ethics of care matter in education?
}



When a black 2nd-year student educator gets chased away from a school whilst doing his teaching practice for hair 'not setting an appropriate example to learners', the incident elicits questions about the rights of student educators during teaching practice, as well as the extent to which universities and schools care for, support and prepare student educators for the realities of schooling in South Africa. I situate the article in Transformation in Higher Education and the discourses of moral education concerning universities' preparation of student educators in conjunction with schools in South Africa. The purpose in this article is to critically evaluate the neoliberal regulatory environment that frames education in general and how this has led to 'uncaring' environments in which student educators must operate during the execution of their teaching practice. I applied an ethics-of-care- approach to conceptually discuss the central role that care should play in the professional development of student educators. A decline in the level of care for student educators during teaching practice by universities and schools has an increasingly negative impact on their professional preparation which might lead to increased teacher attrition and discourage new entrants to the profession. To achieve the kind of care among teachers we envisage through education, universities and schools will have to re-examine the role of care for student educators during teaching practice.

Keywords: neoliberalism; education; minimised care; ethics care; ubuntu-care.

\section{Introduction}

The study draws on a recent incident where a student educator was chased away from a school whilst doing teaching practice (TP) for 'not having appropriate hair'. The incident was discussed and debated on Facebook ${ }^{1}$ between an education reporter, the lifestyle editor of Rapport and two reporters and an education law specialist. An investigation by the education department ${ }^{2}$ found that the principal indeed acted wrongly prompting an apology from the provincial Ministry of Education ${ }^{3}$. This incident also drew criticism from political parties who believed the incident to be racially motivated ${ }^{4}$.

The incident occurred when a black student educator from Stellenbosch University (SU) reported for duty at a former Model C school and was asked to leave the school by the school's white principal for allegedly not having hair 'which sets an example to learners'. Apart from the immediate racial tension that the incident generated, the school principal justified his actions to the media by making more racially insensitive comments in which he equated the student educator's hair to that of circus animals. Furthermore, he flouted ethical and procedural regulations when he unilaterally denied a student educator from the opportunity to complete his TP in a public school. Neither SU, nor the Western Cape Education Department (WCED) restored the student educator's right to continue his TP at this specific school. This contributed to the student educator's traumatic experience. The student had to find another school on his own, where he could continue his TP. The incident is not only a vivid reminder of the continued precarious race relationships in South African schools and some hegemonic exclusionary practices that still exist in some schools but it also sheds light on the lack of sufficient care for student educators by universities and schools during TP.

The relevance of this incident is that it resonates with similar incidents of systemic and structural racism against black bodies in South Africa (Delmas High 2020; Pretoria Girls High 2016; Sans

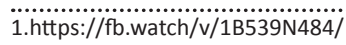

2.https://www.netwerk24.com/Nuus/Onderwys/hoof-beboet-gewaarsku-na-hy-studente-onnie-wegjaag-20210407

3.https://www.iol.co.za/capeargus/news/schaefer-apologises-to-student-for-bleached-hair-incident-principal-charged-026477d6-fc354277-87d1-78878662200d

4.https://briefly.co.za/95418-eff-demands-vredenburg-primary-school-principal-be-suspended-racist-comment.html. 
Souci 2016) ${ }^{5}$ and around the world (Bushby 2020; Gatwiri 2018; Sini 2018). The struggles of identity and culture these learners are facing in South African schools can be linked to broader struggles as seen in the Black Lives Matter movement around the world (Henkeman 2018). The social problem that is addressed is how educational institutions devoid of care can adequately prepare student educators to navigate schools as agents of 'peacebuilding' and 'social cohesion' (Cappy 2016:122).

The problem I address in this article is the place of care in student educators' professional development in an education system strongly framed by neoliberalist (Adams 2006; Hall 2011; Maistry 2014; Marois \& Pradello 2015; Rustin 2016; Shenk 2015; Sparkes 2007; Van der Walt 2017; Welch 1998) and perfunctory logics (Naidoo 2001:107). The concern is that, in quantitatively focused and highly regulatory environments, universities and schools' caring for student educators' professional development during teaching practice has become increasingly neglected. If left unchecked, the concern is that universities will produce teachers who can teach, but who are mechanistic in their approach to their work - robot-like teachers who simply deliver the curriculum uncritically without the intent of caring for the 'enhancements of peoples' lives' whom they are teaching (Wong \& Wong 2004:21). 'Minimised care' says Cherrington (2017:73), renders teachers to mere transferers of knowledge from books, apathetic to cultural diversity, social justice and how to live as active citizens. The institutional cultures of universities and schools have become focused on accreditation, assessment and pass-or throughput-rates, which are better than that of the competition. The traditional ideals of education as a vehicle to 'transform society'; 'to liberate people from the grasp of poverty' and education as 'the practice of freedom' (hooks 1994:207) seem to have been largely replaced by a focus on skills acquisition for the market. Values and community well-being in schools are mentioned in passing, whilst the real focus in terms of time, capital and infrastructure is geared towards production (of pass rates, throughput rates and international rankings). Uncaring educational environments expect school teachers to be docile and compliant workers in prescribed bureaucratic school systems whilst universities are expected to produce readymade teachers who can fit into schools' operating systems, seamlessly. The business of education at universities and schools is so fast-paced that there is little time for individual attention to student educators or learners. And whilst we are producing better pass rates and more graduates,

5.Pretoria High School for Girls is a former white peoples' only school where black learners were constantly targeted (pulled out of class, singled out or endured snide remarks from teachers) for their natural hair not being fit for the school. White schoolgirls shaved off all their hair in solidarity with their black fellow students. This incident sparked a national outcry against racism in the country during 2016. Black learners at Sans Souci Girls' High School in Cape Town in 2016 were locked out of the school after they began demonstrating against school rules and teachers who penalised learners for speaking black South African languages and for wearin penalised learners for speaking black South African languages and for wearing natural hair on school grounds. The provincial education department in which the school is situated concurred that this school allowed discriminating practices but also indicated that no one would be dismissed. This story also sparked a nationa debate on continued racist practices against black learners in former white peoples only school. Strict hair policies for African hair drew the ire of the media at Delmas High School (another former white peoples' only school) in Mpumalanga in 2020 The school denied the claims and the provincial education department refused to comment on the issue. education does not appear to change society for the better. As Jacobs (2005:794) referred to 'the essence of hope', I would like to add that care too, is 'a necessary condition for an education aimed at bringing about social change'. In the following section, I briefly discuss my methodological approach.

The article aims to bring the issue of care for student educators during TP to academic consciousness. It draws from a recent incident at a school where a black student educator was chased off the school premises of a public school by a white school principal. The emphasis on race is important because the principal's justifications for his actions speak to the ongoing issues of race and power in South African schools. More importantly although, which is also the focus of the article, is the apparent lack of care by the university (when it does not restore the student's right to continue his TP at this particular school) and the school (in its punitive treatment of this student educator with complete disregard of legal, professional and ethical protocols). An 'ethics of care' is proposed as an alternative approach to student educators during TP irrespective of the highly regulated environments now dominating educational spaces. n.p

\section{Methods}

This article followed an interpretive perspective to analyse the place of care for student educators during TP. I used a conceptual research methodology concerning the research on care in education by analysing the incident where the student educator was banished from a public school. Following Terre Blanche, Durrheim and Painter's (2006:557) claim that a conceptual study is a process whereby a researcher develops a clear and explicit theoretical image or idea of the issue to be understood, I combined previous research on care and associated work (ethics, justice) in education to critically discuss the current phenomenon of dwindling care for student educators during TP. Based on various ethics of care approaches, I proposed alternative approaches to address the 'lack of care' crisis in education.

\section{Teaching practice in a regulated environment}

Under the current neoliberalist policy regulation and high quantitative demands, the culture in educational institutions has been corporatised, commodified and privatised. In his article, entitled: Neoliberalism Doesn't Care, Koechlin (2021), describes neoliberalism amongst others as:

$[\ldots T]$ he aggrandizement of the market and the disparagement of the state; the aggrandizement of private property and the disparagement of the commons; the privatization of social security and the relentless insistence that we 'can't afford' medical aid; International Monetary Fund (IMF) structural adjustment programs; tax cuts for the rich; the prioritization of property and the 'freedom' of property owners over people; profits before people; austerity; the insistence that we should thank big capital for exploiting human beings and the planet; the insistence that we should facilitate - by deregulation, liberalization and privatization - big capital's exploitation of human beings and the planet. (n.p) 
One of the consequences of a neoliberalist education system is the dehumanisation of the educational project in which stakeholders (university teachers, schoolteachers and in this specific case, student educators), are often marginalised and exposed to exploitation. To this end, Ball (2003:216) observed that the new technologies of reform play an important part in aligning public sector organisations with the methods, culture and ethical system of the private sector'.

Educational policy reforms in South Africa have shifted from their original people-centred, caring ideals to marketorientated objectives that seem far removed from caring for the people. Mathebula (2018:97-99) in Human rights and neoliberal education in post-apartheid South Africa, explained that neoliberalist agendas have rather sought to expand global capital accumulation through free trade, financial deregulation and privatisation. He quoted Hanson and Hentz's (1999) research that indicates that the African National Congressgovernment's (ANC) education budgets are now depoliticised and removed from the realm of public debate and placed in the hands of economists and technocrats (p. 97). Furthermore, he argued, by drawing on Harris (1997) that schools are now simply viewed as units of products whose performance is regulated by the mechanism of consumer choice based on information about their effectiveness and efficiency (p. 98). He added via Chisholm and Fuller (1996:693) that the government's idea of 'people's education and robust community participation gave way to a technocratic discourse that 'relieved the Right and bewildered the Left'. Business interests in schools (through upskilling, life-long learning and transferable skills), he adds by drawing on Phillips (1998), now seem to proliferate. Finally, he asserted that the rights and responsibilities of communities, parents and learners and other interest groups in education (such as student educators) [my emphasis], seem to be defined 'as those of consumers of the products of education rather than those of participants in education' (Fuller 1996:693).

The ideas of collectivity, community and inclusivity in universities and schools have been reduced to public relations exercises. People in these sectors are now required to act as individuals who need to think for themselves and take care of themselves. The idea of a community of practice had to make way for a new kind of culture in higher education that of commercialisation, corporatisation, commodification, privatisation and marketisation of the public university (Giroux 2014; Marginson 2016a, 2016b; Shore \& Wright 2016; Slaughter \& Leslie 1997). 'Financial motivations' (Rabovsky 2012), not 'the public purpose' (Shapiro 2005), nor the 'emancipation of the individual' (Mokyr 2002) seemed to have turned higher education institutions and schools into global market environments divorced from their redefined social contract (Brennan 2004). In South African universities, similar impulses have led Swartz et al. (2019:576) to assert that the pressures both upon and within universities have led to serious reflection about the very nature of these institutions and what should constitute their "core business."' Core business, a notion itself steeped in a history of corporate governance has subsequently been applied to higher education. Amid deep prevailing inequalities in the South African higher education sector, the context in which they are located and the growing marketisation of higher education, bring the primary and overriding purpose of the university into question (Swartz et al. 2019).

In assuming the role as preparers of educators for South Africa, universities (in collaboration with schools) serve as learning communities in which novice educators learn the theoretical and practical fundamentals of their profession. In such a community, one can reasonably expect the novice to make mistakes along the way, in the process of becoming a full member of the teaching community. Mistakes, one would imagine, would be dealt with in a caring, supportive way, where the incumbent learns by doing, guided how to do, and redoing. Teaching practice is intended to provide student educators with a learning-by-doing opportunity. Teaching practice is the period during their training where student educators gain real-life experience in the actual teaching and learning environment (schools). Learning about the profession in real-life situations is supposed to be a supportive and caring experience in nurturing spaces where novice educators are supposed to become embedded in communities of practice.

Teaching practice is framed by national and provincial regulations. To become a teacher in South Africa, one must have a 3-year bachelor's degree with a Post Graduate Certificate of Education (PGCE) or a 4-year B.Ed. degree at a recognised higher education institution. This will allow a newly qualified teacher to register with the South African Council of Educators (SACE), the national regulatory body for teachers in South Africa, and obtain a license to teach. Universities take responsibility for the preparation of student educators. As part of this university's teaching degree, a credit or 'pass' mark in TP is a prerequisite indicator that a student educator has acquired competence in the classroom.

Theminimum requirements for teacher education qualifications (MRTEQ) views work-integrated learning or TP as central to the professional development of teachers (Department of Higher Education and Training [DHET] 2011). Teaching practice, the DHET envisages, has both a developmental and evaluative purpose and should thus be both supervised and assessed. Practical learning provides student educators with an opportunity to engage with the realities of teaching in schools. Teaching practice is an important condition for the development of tacit knowledge, which is an essential component of learning how to teach. To support their professional development, Ruznyak and Bertram (2013) asserted, TP provides students with opportunities to develop their tacit practical knowledge as they learn from practice (e.g. observing and reflecting on lessons taught by others), and learn in practice (e.g. preparing, teaching and reflecting on lessons they presented). In support of their professional development, the practicum provides students with opportunities to develop their tacit practical knowledge as they learn from practice (e.g. observing and reflecting on lessons taught by others), and learn in practice (e.g. preparing, 
teaching and reflecting on lessons presented by oneself) (DHET 2011:8).

In the Western Cape (the province in which the incident took place), the education governing authority in the province, WCED, SU (one of three universities in this province), and its partnering schools have a mutual agreement and policy framework as a basis on which TP takes place in the province. The Professional Development Strategy of the WCED addresses the professional preparation of student educators and declares that preparing and recruiting student educators to become good is a central strategy in improving the quality of learning and teaching in every school in the province. Close cooperation between universities and schools where students are engaged in TP is of critical importance for the WCED to secure successful partnerships between role players, the effective delivery of competent educators, and a seamless introduction into schools and daily classroom realities (WCED [Protocol for Teaching Practice in Western Cape] 2020:3).

Universities, together with the WCED prepare student educators for the world in which they will work based on a 'Work Integrated Learning' (WIL)-approach. Work Integrated Learning is the range of approaches and strategies a student educator would use to integrate theory with practice. Student educators are required to use a WIL approach during their TP. Paragraph 3.1 of the Protocol for TP states that WIL takes place in the workplace and can include aspects of learning from practice. Work Integrated Learning is a key element of a holistic educational strategy to integrate real-life experiences into the education curriculum.

When a student educator from a university in the Western Cape arrives at a school in the province, he or she does so in terms of national, provincial and locally agreed upon, rules, goals and expectations. But, not all schools in the province are the same (as is the case in the rest of the country). Christy and McKenny (2017), in Decoloniality and 'Model C' schools: Ethos, language and the protests of 2016, provide a useful description of the differences in schools as part of the country's negotiated settlement in the early 1990s so this study will not cover that aspect. Tensions about transformation and issues of diversity in 'Model C' (former designated white schools and now just public schools') however continue and might have been an underlying cause in this particular incident where a black student educator is chased off the premises of a public school by a white school principal.

\section{What are the challenges?}

The chasing away of this student educator raises legal, procedural and ethical challenges. Although a student educator, whilst doing TP, is a guest of a school and can be expected to abide by the rules of the school, school rules or codes of conduct ought to be drawn up by a school's governing body (SGB), board or council in consultation with all stakeholders and communicated to all concerned parties. In terms of the South African Schools Act (Act 84 of 1996), school rules must be drawn up by a SGB in conjunction with all the stakeholders in the school. What is more important is that these rules should be communicated to all stakeholders as well. In this sense, this particular school's rules or expectations around teachers' hair should have been communicated to the university, but it was not. Another thing about school rules is that they should be representative of the relevant school's population. It is suspected that this was not the case in this instant and that this particular school, like many other public schools in the country, is still struggling with formulating such rules.

Ethically, educators' (including school principals) interactions in schools are regulated by a Code of Professional Ethics as set out in the Guidelines of the South African Council for Educators (SACE) (RSA Act 31 of 2000) and include refraining from undermining the status and authority of an individual and avoiding any form of humiliation (DoE 2000b). Under normal circumstances and per procedures set out in SACE, a principal would call a colleague or student educator aside, pointed out his unhappiness in a professional conversation with a colleague and reported the incident to the university's liaison officer overseeing TP. This did however not happen in this instance. Instead, the principal shouted at the student educator, gave him no chance to state his side of the story and ended his TP opportunity with immediate effect (Slatter 2021). In an already politically charged environment, the altercation between a black student educator and a white school principal, evokes images of continued unfair treatment of particular groups of people in South Africa. The inaction by the University and WCED to restore the student educator's right to continue his TP at the school of his choice, highlights the apparent reluctance to address the concerns of racism against black people in post-Apartheid, x Model C-schools.

This situation is in stark contrast to Aristotle's views of the primary goal of education as teaching moral virtues, which encompasses two complementary parts (ethics and practical wisdom) (Chen 2019:97). Paul and Elder (2006) defined ethics as 'a set of concepts and principles that guide us in determining what behaviour helps or harms sentient creatures'. Ethics, according to Edwards (2008:78), refers to morality. Caring is an overarching quality that gives the action its moral character (Van Hooft 1999; Wadesango \& Machingambi 2015). In operationalising ethics of care within educational institutions, Kgomotlokoa et al. (2016:93) argued that moral development is the responsibility of all those involved. Jansen (2011) added that the moral growth of the members is the responsibility of the community such as student educators, universities and schools. But, as Harvey (2007) warns in Neoliberalism: Creative Destruction, the neoliberal character that has engulfed universities and schools signalled a noticeable transition in the purpose and character of educational institutions from places of social cohesion and care to places with hollowed-out corporate cultures defined by regulation, policies, rules and perfunctory routines.

The result is that, in the absence of a community of care, student educators and even practicing educators find it more difficult to cope in school environments. Botha and Rens (2018) 
use the term, 'reality shock' to question the adequacy of universities' teacher preparation programmes to adequately prepare South African teachers to cope with the 'uncaring' environments of South African schools. New teachers often find the transitioning from the missionary ideals at university to the rude realities of school classrooms, difficult. Whilst the university often focuses on an inductive student-centred approach where the learner as co-constructor of knowledge is emphasised, schools demand a deductive teacher-centred approach where curriculum knowledge is transferred from teacher to student. Classroom management and discipline remain huge challenges. Teachers often find workloads (extramural activities, communication with parents and colleagues, and particular school leadership and management styles (Botha \& Rens 2018:1-8), overwhelming. FeimanNemser (2001:1016) described the gap between student educators and the real world of school as the 'challenges of reconciling learned experience with realities of teaching'. Upon entering schools, teachers are faced with the highly regulative and quantitative demands of the education system; deep inequalities between schools in South Africa in terms of resources and mentorship support and violence in communities beset with historic socio-welfare challenges, which often spill over into schools. Universities' teacher preparation programmes are often focused on pedagogical and theoretical knowledge and do not always deal with the practical challenges of schools. Teacher preparation programmes at universities thus often fail to adequately prepare new entrants to the teaching profession for the uncaring realities of school, which leaves student educators and new teacher entrants fragile and vulnerable.

What neoliberalism cleverly does is take liberal ideas and virtues and add to it a narrowly focussed laissez-faire economic twist. Education, which is supposed to be a public good for all, through a neoliberalist lens, thus becomes another opportunity for profit and competition, which ultimately leads to exclusivity, inequality and elitism. The idea of individual rights becomes understood as minimum government interference in economic issues of individuals. Neoliberalism often centres on individualism, independence and self-responsibility. Ball (2003:129) used, 'self-governance to refer to the responsibility on individuals' shoulders in the current education environment. The ideas of self-governance and self-regulation assume that individuals take responsibility for their actions. The individual is now solely responsible for their own well-being in the education system. This seems almost antithetical to the idea of preparing aspirant educators who are dependent on a community of lecturers and practicing teachers for their professional development. During TP, student educators are still learning the trade and are bound to make mistakes. One can imagine that these individuals still need guidance in a caring, non-punitive manner.

Self-responsibility is the case referred to in this study, which appeared to have implied that the student educator takes ownership of the situation he finds himself in and manages the impasse between him and the principal himself. Up against the power vested in the school principal (being a representative of the state and a member of the SGB at the same time) and the lack of intervention from his university or WCED to restore his rights to continue his TP at that specific school, however, the student educator felt isolated, unsupported and left to his own devices. He had to go and 'find another school by himself' to continue his TP (Slatter 2021). The hidden danger in the idea of outsourcing responsibility to the individual instead of the collective then is that it may lead to the exploitation of individual rights. In this specific case, the incident left the individual 'feeling isolated, hurt and powerless' (Slatter 2021). Although teaching practice is a valued and fundamental tradition in the development and socialisation of teachers, Mukeredzi \& Mandrona (2013:1) argue that "it has challenges, especially in rural areas where lack of in-school support and guidance can reduce its effectiveness". Their research into students' experiences of TP found that unsupportive school contexts and problematic interactions between student educators, mentors, other staff and the initial encounters with learners as some of the main sources of frustration, anger and bewilderment amongst student educators (p. 149). What alternatives can be offered?

\section{Towards an ethics of care}

Responsive educational institutions respond proactively and sympathetically to appeals, efforts and influences and address needs so that all can thrive in the institution. To be culturally responsive, Maluleka (2020:141) expands, means that there are proactive and empathetic efforts to comprehend, respect, and meet the needs of those coming from dissimilar cultural backgrounds. For education departments, universities and schools this means being open to other ways of understanding and being in the world, having different hairstyles and different ways of expressing oneself in an educational space so that concerns of continued colonialism in our educational institutions (Fataar \& Subreendith 2015:107) can be quelled.

Care ethics is rooted amongst others, in the writings of Gilligan (1982) and Brabeck (2000) in Psychology, Noddings (1984/2003) in Philosophy and Social policy (Noddings 2002b); Politics (Tronto 1993) and Ubuntu (Waghid 2018). Developing empathy for others is a fundamental component to forming active, curious, capable and caring citizens, says Nussbaum (2010:72). But with education's focus now highly premised on neoliberal market arrangements, a 'crisis of care' has developed (Fraser 2016).

For Carol Gilligan (1982) an ethics of care is central to democratic, inclusive human actions. In her book, In a different voice, she contends that caring is a form of human attachment (Gilligan 1982:63) according to which humans do not act hurtfully towards others. Caring is a relational act that is conceptually linked to inclusion. In the context of this case, it means that a student educator's voice cannot be 
silenced when he or she speaks out when experiencing violation and exclusion.

Educational institutions that care for their students are attentive to their students' concerns. For Gilligan (1982), an ethics of care is an ideal relationship in which:

... Self and others will be treated as of equal worth, that despite differences in power, things will be fair; the vision that everyone will be responded to and included, that no one will be left alone and hurt. (p. 63)

In Nel Noddings's (1984) work, Caring: A feminine approach to ethics and moral education, she argues for practical, relational acts of caring in education based on modelling, dialogue and recognition. Extending Gilligan's notion of inclusive caring, Noddings (1992:21) added, that caring also recognises the mutual part played by the cared-for in 'an ethic of relation'. Modelling, dialogue and recognition form the building blocks of her ideas of practical caring (Noddings 1984). This implies that we show students that they are being cared for by creating caring relations with them. According to Noddings (1992:25) recognition links the practice of caring to affirmation and encouragement of others. Recognising and affirming who students are (historically, culturally, economically, politically) in the university- and by extension, schools- is vital in re-orientating us toward a better vision of ourselves as human beings. In Noddings' terms, caring is thus an act of community underscored by practical acts of care.

The Freirean view of care in education is the advancement of human rights and the dignity of the people it is supposed to serve. As a tool for liberation and a pedagogy of caring, Freire agitated for education in which justice and respect for the dignity of every person was an ethical imperative (Freire 2001:59). At the centre of caring for Freire, was the idea that communal action between students and educational authority ought to prevail. Given the oppression suffered by the majority of black people in South Africa, the many inequalities remaining and the repeated dehumanising experiences black people continue to suffer in the country, a Freirean perspective encourages a more humanitarian approach. Freirean mindedness requires us to become aware of oppressive situations, call them out for what they are and actively change injustice.

Tronto (1993:134-135) opined that caring is the moral element in responsiveness concerned with vulnerability and inequality that belies the myth of citizens always being autonomous and potentially equal. To provide ethics of care in an unequal education system, responsiveness requires a consideration of the other's position as expressed by them. This implies an engagement with others from their standpoint, placing your assumptions of their experiences aside. Tronto's four-phased approach to care is useful to consider the potential gaps in our educational institutions' pedagogy of care. Tronto (2014a) bemoaned the fact that many theorists regard justice and care as separate spheres in which different forms of ethical reasoning are applied. Yet the relationship between justice and care had been explicated adequately in Moral Boundaries (Tronto 1993), which concluded with the assertion that:

Care is a necessary, though not by itself a sufficient part of our account of moral life. To address and to correct ... [existing] problems with care ... requires a concept of justice, a democratic and open opportunity for discussion, and more equal access to power. (p. 154)

Tronto regarded care as both a standard against which to assess 'how well or how badly care is accomplished in any given society' and a practice that 'puts moral ideals into action' in that 'by focusing on care, we focus on the processes by which life is sustained, we focus on human actors acting' (Tronto 1993:153). If Tronto's (2010:32) assertion, that care 'starts from the premise that everything exists concerning other things' is to be believed, we must rethink our responsibilities of actively caring for student educators to protect their dignity during TP. Active caring as a relational practice, says Tronto (2015):

[S]hapes what we pay attention to, how we think about responsibility, what we do, how responsive we are to the world around us, and what we think of as important to life. (p. 8)

Care-based pedagogical and management approaches in educational institutions relate to how people within an organisation identify, respond to and take responsibility for care (Tronto 1993). Care-based approaches to student educators during TP can provide a much-needed balance to the current one-dimensional views of them in our universities and schools. But caring is also a political act that requires the powers that be to acknowledge that there is a difference between being right and being just. The school principal could be legally right to address staff on any issue, but the way he does so in this case (equating the student educators' hair to circus animals) brings into question whether his actions were just. Section 9(3) of the Constitution of the Republic of South Africa (RSA Act 108 of 1996), indicates that:

The state may not unfairly discriminate directly or indirectly against anyone on one or more grounds, including race, gender, sex, pregnancy, marital status, ethnic or social origin, colour, sexual orientation, age, disability, religion, conscience, belief, culture, language and birth. (p. 6)

Section 12 confirms that everyone has the right 'to be free from all forms of violence and not to be treated or punished in a cruel, inhumane or degrading way' (RSA 1996:30). Furthermore, Section 23 of the constitution also provides that everyone has the right to fair labour practices. School rules and values are supposed to be based on constitutional rights and national education policies and nobody can just make up their own rules as it appears to be the case here.

Slote (2007) linked empathetic caring with the recognition of pain and vulnerability of someone else and by extension, to justice. According to Slote (2007:167-168), social institutions are just if they reflect empathetical caring with regard to marginalised people and do not turn a blind eye to development, intolerance and injustice. Empathetic care 
towards student educators will go a long way to support novice educators' professional development.

Human beings are interdependent on one another. To this end, Waghid (2018:61) suggested 'Ubuntu [care] as a more humane alternative to uncaring environments'. Ubuntu is the African philosophical idea of 'I am who I am because of others'. According to Metz (2007), Ubuntu is the idea that a human being can sustain a harmonious relationship with other human beings through virtues of compassion, forgiveness, generosity and hospitality. The essential idea of a person being and becoming because of his or her community was embedded in South African societies before Industrialisation and modernisation (Mwipikeni 2018). However, he argues, the violent immersion of Africa into colonial modernity brought about the disappearance of the communalistic sociocultural conditions and replaced them with the logic of individualism (Mwipikeni 2018:323). The idea of Ubuntu is very relevant as a moral framework in current times where society is dominated by a politico-juridical order and where neoliberal economic systems that promote individualism and unequal distribution of wealth continue to marginalise the majority of black people. For Waghid, Ubuntu care can affect hospitable and hostile encounters that are both respectful and compassionate. Moral respect for all, Waghid asserts, is a practice of Ubuntu care (Waghid 2018:90) whereby the recognition and acknowledgement of others is always prioritised. Dismissing people based on cultural, political and ethnic differences, as has happened in the incident this study draws on would, for him, be 'an act of remission in the sense that no one can or should wish others away or consider others as unworthy'.

Ubuntu caring provides an opportunity for human beings to treat one another with dignity and respect and to aspire towards moral actions such as humanness and non-violence (Waghid 2018:91). In the face of diminishing care for student educators in our universities and schools, Ubuntu caring is welcoming one another based on being human. This kind of caring can help educational institutions to move beyond the strangleholds of colonialism, post-colonialism and neoliberal market forces that beset universities and schools. Ubuntu caring requires people to engage with one another's cultural, political, socio-economical, and ethnic concerns. If this happens, Ubuntu caring offers an opportunity to rehumanise societies (Waghid 2018:162) and stimulate universities and schools to work towards decoloniality in the quest to undermine racism, exclusion, humiliation, deforestation and other forms of human and non-human injustices.

\section{Conclusion}

A black student educator being chased away from a school with a white institutional culture not only reminds us to remain vigilant against continued prejudices in education but also offers us an opportunity to revisit the implications of care for student educators during TP. By working together in communities of practice (Wenger 1999), universities and schools can create reflective spaces where issues such as hair, dress codes and behaviour can be discussed and ironed out. Gilligan, Noddings, Freire and Tronto show us the importance of ethics of care from various perspectives. Waghid's Ubuntu care offers us another tool to use to move towards a caring mentality of respect in our universities and schools. If we take the time to reconsider ourselves in relation to others - to care again - we stand a better chance of speaking up back and disrupting uncaring and unjust practices in education. To understand individual lives, however, we need to understand the times in which we live and the circumstances of other people. If we are going to achieve the kind of future we envisage through education, then educational institutions must embrace an ethics of care based on shared values.

\section{Acknowledgements Competing interests}

The author declares that he has no financial or personal relationships that may have inappropriately influenced him in writing this article.

\section{Author's contributions}

J.P.J. is the sole author of this research article.

\section{Ethical considerations}

This article followed all ethical standards for research without direct contact with human or animal subjects.

\section{Funding information}

This research received no specific grant from any funding agency in the public, commercial or not-for-profit sectors.

\section{Data availability}

Data sharing is not applicable to this article as no new data were created or analysed in this study.

\section{Disclaimer}

The views and opinions expressed in this article are those of the authors and do not necessarily reflect the official policy or position of any affiliated agency of the author.

\section{References}

Adams, F., 2006, 'Managerialism and higher education governance: Implications for South African Universities?', South African Journal of Higher Education 20(1), 3-14.

Ball, S., 2003, 'The teacher's soul and the terrors of performativity', Journal of Education Policy 18(2), 215-228. https://doi.org/10.1080/0268093022000043065

Botha, C. \& Rens, J., 2018, 'Are they really “ready, willing and able?” Exploring reality shock for beginner teachers in South Africa', South African Journal of Education 38(3), 1-7. https://doi.org/10.15700/saje.v37n3a1377

Brabeck, M., 2000, 'Lawrence Kohlberg', in A. Kazdin (ed.), Encyclopaedia of psychology, vol. 4, pp. 453-454, American Psychological Association, Washington, DC.

Brennan, J., 2004, 'The social role of the contemporary university: Contradictions, boundaries and change', in Ten years on: Changing education in a changing world, pp. 23-54, Centre for Higher Education Research and Information, Open pp. 23-54, Centre for High
University Press, Maidenhead.

Bushby, E., 2020, Pupil repeatedly sent home from school over afro hair wins $f 8,500$ payout, viewed 11 March 2021, from https://www.independent.co.uk/news/ education/education-news/afro-hair-discrimation-student-legal-action-payoutruby-williams-urswick-school-a9323466.html 
Cappy, L., 2016, 'Shifting the future? Teachers as agents of social change in South African secondary schools', Education as Change 20(3), 119-140.

Chen, S., 2019, 'The stages of moral education in Aristotle's ethics and politics', Rhizomata 7(1), 97-118. https://doi.org/10.1515/rhiz-2019-0004

Cherrington, A., 2017, 'Positioning a practice of hope in South African teache education programmes', Educational Research for Social Change 6(1), 72-86. https://doi.org/10.17159/2221-4070/2017/v6i1a6

Chisholm, L. \& Fuller, B., 1996, 'Remembering people's education? Shifting alliances, state-building and South Africa's narrowing policy agenda', Journal of Education Policy 11(6), 693-716.

Christie, P. \& McKinney, C., 2017, 'Decoloniality and "model C" schools: Ethos, language and the protests of 2016', Education as Change 21(3), 1-21.

Department of Higher Education and Training (DHET), 2011, National Qualifications Framework Act 67 of 2008: Policy on the Minimum Requirements for Teache Education Qualifications, DHET, Pretoria.

Edwards, T., 2008, 'Ethical fitness for accountable public officials: An imperative for good governance', Journal of Public Administration 42(5), 28-34.

Fataar, A. \& Subreendith, S., 2015, 'The search for ecologies of knowledge in the encounter with African epistemicide in South African education', South Africa Journal of Higher Education 29(2), 106-121. https://doi.org/10.20853/29-2-468

Feiman-Nemser, S., 2001, 'From preparation to practice: Designing a continuum to strengthen and sustain teaching', Teachers College Record 103(6), 1013-1055. strengthen and sustain teaching', Teachers
https://doi.org/10.1111/0161-4681.00141

Fraser, N., 2016, 'Contradictions of capital and care', New Left Review, July-August 2016, pp. 99-117.

Freire, P., 2001, Pedagogy of freedom: Ethics, democracy, and civic courage, Rowman $\&$ Littlefield, Lanham, MD.

Gatwiri, K., 2018, The politics of black hair: An Australian perspective, viewed 11 March 2021 from https://theconversation.com/the-politics-of-black-hair-anaustralian-perspective-93270.

Gilligan, C., 1982, In a different voice: Psychological theory and women's development, Harvard University Press, Cambridge, MA.

Giroux, H., 2014, 'Beyond the swindle of the corporate university: Higher education in the service of democracy', Truthout, viewed 01 February 2011, from https:// truthout.org/articles/beyond-the-swindle-of-the-corporate-university-highereducation-in-the-service-of-democracy/

Hall, S., 2011, 'The neoliberal revolution', Cultural Studies 75(6), 705-728.

Hanson, M. \& Hentz, J., 1999, 'Neocolonialism and neoliberalism in South Africa and Zambia', Political Science Quarterly 144(3), 479-502.

Harris, A., 1997, 'The deprofessionalisation and deskilling of teachers', In K. Watson, K. Mogdil \& S. Mogdil (eds.), Education dilemmas: Debate and diversity - Teachers, Mogdil \& S. Mogdil (eds.), Education dilemmas: Debate and diversi
teacher education and training, pp. 57-65, Cassell, London, UK.

Harvey, D., 2007, 'Neoliberalism as creative destruction', in The annals of the American academy of political and social science, March 2007, vol. 610, NAFTA and beyond: Alternative perspectives in the study of global trade and development (March 2007), pp. 22-44, Sage, Thousand Oaks, CA.

Henkeman, S., 2018, How violence and racism are related, and why it all matters, viewed 11 March 2021, from https://theconversation.com/how-violence-andracism-are-related-and-why-it-all-matters- 65738.

hooks, B., 1994, Teaching to transgress: Education as the practice of freedom, Routledge, New York, NY.

Jacobs, D., 2005, 'What's hope got to do with it? Towards a theory of hope and pedagogy', JAC 25(4), 783-802.

Jansen, J., 2011, 'Time to bring back the nuns', in the Interview created by Emily Gambade, Daily Maverick.

Kgomotlokoa, L., Kanjere, M.M., Malatji, S. \& Wadesango, N., 2016, 'The importance of ethics of caring in South African Higher Education", Journal of Social Science 47(1), 90-97. https://doi.org/10.1080/09718923.2016.11893547

Koechlin, T., 2021, 'Neoliberalism doesn't care', Common Dreams, viewed 26 March 2021, from https://www.commondreams.org/views/2021/03/20/neoliberalism -doesnt-care

Maistry, S., 2014, 'Education for economic growth: A neoliberal fallacy in South Africa!', Alternation 21(1), 57-75.

Maluleka, K., 2020, 'Humanising higher education through a culturally responsive curriculum', South African Journal of Higher Education 34(6), 137-147. https:// doi.org/10.20853/34-6-3764

Marginson, S., 2016a, 'Public/private in higher education: a synthesis of economic and political approaches', Studies in Higher Education, 1-16.

Marginson, S., 2016b, Higher education and the common good, Melbourne University Publishing, Melbourne.

Marois, T. \& Pradello, L., 2005, Polarising development - Introducing Alternatives to Neoliberalism and the Crisis, Pluto Press, United Kingdom.

Mathebula, T., 2018, 'Human rights and neo-liberal education in post-apartheid South Africa', Journal of Education (71), 93-106. https://doi.org/10.17159/2520-9868/i71a06

Mokyr, J., 2002, The gifts of Athena: Historical origins of the knowledge economy, Princeton University Press, Princeton, NJ.

Mukeredzi, T. \& Mandrona, A., 2013, 'The journey of becoming professionals: Student teachers' experiences of teaching practice in a rural South African context', International Journal of Education Research 62, 141-151. https://doi. org/10.1016/j.ijer.2013.07.010

Mwipikeni, P., 2018, 'Ubuntu and modern society', South African Journal of Philosophy 37(3), 322-334. https://doi.org/10.1080/02580136.2018.1514242
Naidoo, J., 2001, Education decentralization in sub-Saharan Africa: A review of the literature, Harvard Graduate School of Education, Cambridge, MA.

Noddings, N., 1984, Caring: A feminine approach to ethics and moral education, University of California Press, Berkeley, CA.

Noddings, N., 1992/2005, The challenge to care in schools, Teachers College Press, New York, NY.

Noddings, N., 2002b, Starting at home: Caring and social policy, University of California Press, CA.

Nussbaum, M.C., 2010, Not for profit: Why democracies need humanities, Princeton University Press, Princeton, NJ.

Paul, R. \& Elder, L., 2006, The miniature guide to understanding the foundations of ethical reasoning, Foundation for Critical Thinking Free Press, New York, NY.

Rabovsky, T.M., 2012, 'Accountability in higher education: Exploring impacts on state budgets and institutional spending patterns', Journal of Public Administration Research and Theory 22(4), 675-700. https://doi.org/10.1093/jopart/mur069

'“Racist school hair rules" suspended at SA's Pretoria girls' high', BBC News, Augus 20, 2016, viewed 11 March 2021, from https://www.bbc.com/news/world africa-37219471.

Republic of South Africa (RSA), 1996, Constitution of the Republic of South Africa Act 108 of 1996, Government Printer, Republic of South Africa, Pretoria.

Rice, A., 2011, 'Jonathan Jansen: 'Time to bring back the nuns". The Daily Maverick, viewed 03 June 2011, from https://www.dailymaverick.co.za/article/2011-06-03jonathan-jansen-time-to-bring-back-the-nuns/

Rustin, M., 2016, 'The neoliberal university and its alternatives', Soundings 63, 147-176.

Rusznyak, L. \& Bertram, C., 2013, An analysis of teaching practice assessment instruments: A cross-institutional case study of five universities in South Africa, JET Education Services, Johannesburg.

'Sans Souci Girls' High School pupils protest against a "discriminatory" code of conduct', Mail \& Guardian, September 01, 2016, viewed 11 March 2021, from https://mg.co.za/article/2016-09-01-sans-souci-girls-high-school-pupils-protestagainst-discriminatory-code-of-conduct.

Shapiro, H., 2005, A larger sense of purpose: Higher education and society, Princeton University Press, Princeton, NJ.

Shenk, T., 2015, What exactly is Neoliberalism? Interview with political scientist Wendy Brown.) Dissent, viewed 03 October 2016, from https://www. dissentmagazine.org/blog/booked-3-whatexactly-is-neoliberalims-wendybrown-undoing-the-demos htTeaching practices://www.dissentmagazine.org/ blog/booked-3-whatexactly-is-neoliberalims-wendy-brown-undoing-the-demos

Shore, C. \& Wright, S., 2016, 'Neoliberalisation and the "Death of the Public University"', Associazione Nazionale Universitaria Antropologi Culturali (ANUAC). https://doi.org/10.7340/anuac2239-625X-2451

Sini, R., 2018, "US school faces backlash after black student's "unnatural hair" criticised', viewed 11 March 2021, from https://www.bbc.com/news/world-uscanada-45269540.

Slatter, L., 2021, 'Die dae van kibbel oor hare is verby', RapportSA/videos, viewed 23 February 2021, from https://www.facebook.com/RapportSA/videos/4445496 80087556.

Slaughter, S. \& Leslie, L., 1997, Academic capitalism: politics, policies, and the entrepreneuria university, Baltimore, Md., Johns Hopkins University Press, London.

Slote, M., 2007, The ethics of care and empathy, Routledge, New York, NY.

Sparkes, A., 2007, 'Embodiment, academics, and the audit culture: A story seeking consideration', Qualitative Research 7(4), 521-550.

Swartz, R., Ivancheva, M., Czerniewicz, I. \& Morris, N, 2019, 'Between a rock and hard place: dilemmas regarding the purpose of public universities in South Africa', Higher Education 77, 567-583.

Terre-Blanche, M., Kelly, K. \& Durrheim, K., 2006, 'Why qualitative research', In M. Terre- Blanche, K. Durrheim \& D. Painter (eds.), Research in practice: applied methods for the social sciences, 2nd rev. ed., pp. 271-284, University of Cape Town Press, Cape Town.

The Citizen, 2020, 'Fake news: Anger over "racist" hair rules for Hoërskool Delmas pupils', The Citizen, January 16, 2020, viewed 13 July 2021, https://www.citizen. co.za/news/south-africa/education/2229659/fake-news-anger-over-racist-hairrules-for-hoerskool-delmas-pupils/

The Republic of South Africa, 2000, South African Council of Educators (Act 31 of 2000), Government Printers, Pretoria.

Tronto, J.C., 1993, Moral boundaries: A political argument for an ethic of care, Routledge, New York, NY.

Tronto, J.C., 2010, 'Creating caring institutions: Politics, plurality, and purpose', Ethics \& Social Welfare 4(2), 158-171. https://doi.org/10.1080/17496535.2010.484259

Tronto, J.C., 2014a, 'Moral boundaries after 20 years: From limits to possibilities', in G. Olthuis, H. Kohlen \& J. Heier (eds.), The significance of Joan Tronto's argument for political theory, professional ethics and care as practice, vol. 9, pp. 9-26, Peeters: Ethics of Care, Leuven.

Tronto, J.C., 2015, 'Theories of care as a challenge to Weberian paradigms in social science', in D. Engster \& M. Hamington (eds.), Care ethics and political theory Oxford Scholarship Online. pp. 252-271, Oxford University Press, Oxford.

Van der Walt, J., 2017, 'Neoliberalism and education: A reformational-pedagogical perspective', Koers-Bulleting for Christian Scholarship 82(1), 1-11. https://doi. org/10.19108/KOERS.82.1.2275

Van Hooft, S., 1999, 'Acting from the virtues of caring in nursing', Nurse Ethics 6(3), 189-201. https://doi.org/10.1177/096973309900600302 
Wadesango, N. \& Machingambi, S., 2015, 'Instructional strategies for motivating students: Reflections from teaching in higher education', Journal of Education Studies 13(1), 166-185.

Waghid, Y., 2018, Towards a philosophy of caring in higher education: Pedagogy and nuances of care, Palgrave MacMillan, Cape Town.

Welch, A., 1998, 'The cult of efficiency in education: Comparative reflections on the reality and the rhetoric', Comparative Education 34(2), 157-175.
Wenger, E., 1999, Communities of practice: learning, meaning and identity, Cambridge University Press, Cambridge.

Western Cape Education Department, 2020, 'Cape Teaching and Leadership Minute: 0004/2020', (online), viewed 03 June 2011, https://wcedonline. westerncape.gov.za/circulars/minutes20/CMminutes/CTLI/ectli0001-2020.pdf

Wong, H.K. \& Wong, R.T., 2004, How to be an effective teacher in the first days of school, Harry K. Wong Publications, Inc., Mountain View, CA. 